\title{
Cytokine-Induced Killer Cells
}

National Cancer Institute

\section{Source}

National Cancer Institute. Cytokine-Induced Killer Cells. NCI Thesaurus. Code C71757.

A preparation of autologous lymphocytes with potential immunopotentiating and antineoplastic activities. Cytokine-induced killer (CIK) cells are CD3- and CD56-positive, non-major histocompatibility complex (MHC)-restricted, natural killer (NK)-like T lymphocytes, generated ex-vivo by incubation of peripheral blood lymphocytes (PBLs) with anti-CD3 monoclonal antibody, interleukin (IL)-2, IL-1, and interferon gamma (IFNgamma) and then expanded. When reintroduced back to patients after autologous stem cell transplantation, CIK cells may recognize and kill tumor cells associated with minimal residual disease (MRD). CIK cells may have enhanced cytotoxic activity compared to lymphokine-activated killer (LAK) cells. 